The research program of the Center for Economic studies produces a wide range of theoretical and empirical economic analyses that serve to improve the statistical programs of the U.S. Bureau of the Census. Many of these analyses take the form of research papers. The purpose of the Discussion Papers is to circulate intermediate and final results of this research among interested readers within and outside the Census Bureau. The opinions and conclusions expressed in the papers are those of the authors and do not necessarily represent those of the U.S. Bureau of the Census. All papers are screened to ensure that they do not disclose confidential information. Persons who wish to obtain a copy of the paper, submit comments about the paper, or obtain general information about the series should contact Sang V. Nguyen, Editor, Discussion Papers, Center for Economic Studies, Room 1587, FB 3, U.S. Bureau of the Census, Washington, DC 20233-6300, (301$763-2065$ ).

\title{
EXPORT PERFORMANCE AND STATE INDUSTRIAL GROWTH*
}

\author{
by \\ Rodney A. Erickson \\ CES 90-3 January 1989
}


** The Pennsylvania state University 


\section{Abstract}

This research examines whether state industrial growth over the past decade has occurred independently of changes in manufacturing exports and whether export employment growth responds to the same economic and locational forces as employment growth in domestic production. The empirical results indicate that employment and value added growth are not independent of export sales growth; however, a shift toward export markets is not strongly associated with higher manufacturing growth rates. Traditional factors account for a far greater proportion of the variation in domestic than export employment growth. The results suggest the need for additional research on the sources of state comparative advantage in export markets.

*This research was completed while the author was an ASA/NSF/Census Research Fellow at the U.S. Bureau of the Census, Washington, DC. The author gratefully acknowledges the financial support of the National Science Foundation through the American Statistical Association's ASA/NSF/Census Research Program and the research and computational assistance of David J. Hayward. Robert H. McGuckin provided valuable comments on an earlier draft of this paper. The 
conclusions presented here do not necessarily reflect those of the Census Bureau or the funding source. Any errors or omissions are the responsibility of the author. 


\section{Introduction}

The volume of foreign trade between the United States and other nations has increased dramatically in recent decades. The value of U.S. exports of goods and services, measured in constant 1988 dollars, increased from \$132 billion in 1968 to \$520 billion in $1988[19 ; 20]$. Whereas the value of total exports was equal to 5.8 percent of GNP in 1968, this figure had increased to 11.2 percent by 1988, indicative of the larger role played by foreign trade in the national economy $[19 ; 20]$.

Since 1976, the United States has experienced an unbroken string of deficits in its merchandise trade balance, reaching an all-time high of over $\$ 158$ billion in 1987 [21]. While the average annual current dollar value of exports increased by 8.2 percent over the past decade, imports increased by an average of more than 10 percent [21]. Having grown accustomed to trade surpluses before 1970, American businesses, government policymakers, and the general public have reacted with considerable concern to the nation's continuing trade woes, despite much uncertainty in the academic community regarding the economic implications of the trade deficit.

The national introspection and accompanying action agenda surrounding foreign trade have focused on global competitiveness issues and generated a myriad of policies designed to curb imports while enhancing exports. Business associations, especially those in trade sensitive industries such as steel, 
autos, and agricultural products, continually lobby Congress for protectionism in the form of import quotas, tariffs, and other restrictions. Other aspects of recent federal legislation (Omnibus Trade and Competitiveness Act of 1988, PL 100-418) such as the creation of the National Trade Data Bank are designed to increase exports through the dissemination of information on sales opportunities in other nations.

At the state level, governments have also implemented many forms of export promotion programs including trade data banks and export clearinghouses, export "counselors" and seminars, subsidized loan funds for export businesses, trade field offices in foreign countries, and other export-related initiatives. Data indicate that the governments in every state are involved in these endeavors and, in aggregate, they spent more than \$62 million in FY 1988 on international programs [14]. ${ }^{\text {State }}$ export promotion policies are based on the assumption that enhanced participation in foreign exporting leads to greater job increases in the respective host state economies. The explicit or implicit rationale for this assumption seems to be that exporter firms will experience higher than average rates of growth if they can successfully compete in foreign markets, and that these higher rates of firm growth will favorably influence

${ }^{1}$ Data from the National Association of State Development Agencies [14] indicate that, of the 40 states which reported detailed international program budget items, an average of 53 percent of the funding was used for export promotion activities. 
state employment growth generally.

A state's industries can, of course, sell their output in any of several markets including those within their own state, those in other states (usually referred to as interstate and interregional exports), or those in other nations as foreign exports. While the structure and impacts of domestic interregional exports have been extensively studied, research on the implications of foreign exports for state and regional economic change has only recently begun to appear $[5 ; 6 ; 7 ; 8 ; 17]$. Unfortunately these studies are, with a few exceptions [13], typically confined to a single state or region, and estimate only the share of economic activity accounted for by direct and indirect foreign exports for a particular year(s).

The purpose of the research presented here is to examine whether state industrial growth over the past decade has occurred independently of changes in manufacturing shipments sold in foreign export markets. I also explore whether the growth of manufacturing export employment is related to the same economic and locational forces as employment growth for domestic production. The research examines these relationships for the 48 continental states over a recent time period using a variety of published and unpublished data from the U.S. Bureau of the Census and other sources. ${ }^{2}$ The public policy implications of the factors influencing both export- and domestic-oriented industrial

\footnotetext{
${ }^{2}$ Nearly all previous studies of state industrial growth have also been confined to the 48 contiguous states.
} 
growth are also discussed.

\section{Exports and State Industrial Growth: Trends and Relationships}

Several variables may be used to measure state industrial growth and its export and domestic components. Two traditional measures were selected to represent state industrial growth: the change in manufacturing employment and value added. Foreign export variables include the change in the value of shipments of manufacturing direct exports, the change in the value of shipments of total (direct and indirect or supporting) exports, and the change in direct export employment. The total exports shipment variable includes the value of related inputs of intermediate purchases of manufactured goods necessary to produce the direct export shipments and is based on national input-output interindustry transactions estimated by the U.S. Bureau of Economic Analysis. Domestic shipments and employment are the residuals when direct export employment and shipments are removed from the respective state manufacturing totals.

Changes over the 1977-86 time period for the 48 states are used throughout the analysis. A relatively long time interval was chosen to reduce the potential effects of short-term employment and output fluctuations on the relationships between export performance and state industrial growth. The year 1977 was chosen as the benchmark observation because no geographic area data on manufacturing or exporting were compiled by the Census Bureau for the years 1978-81; the ending year 1986 
represents the most recent data available. Both the beginning and ending years also represented expansionary periods in the national economy, and cyclical effects should therefore be minimized.

Over the 1977-86 period, manufacturing employment averaged across the 48 states fell by 1.1 percent, while real value of shipments increased by 25.0 percent and real value added increased by 32.9 percent. However, the real value of foreign export shipments grew even faster; direct manufacturing export shipments increased by an average of 60.4 percent across states and total export shipments increased by 70.6 percent. These increases in export sales were accompanied by an increase in direct export employment of 26.9 percent and an increase in total export employment of 34.8 percent. These data indicate that the value of foreign export shipments has been growing faster than the typical state's total manufacturing shipments in recent years, and cast further doubt on prevailing public perceptions concerning the presumed inability of U.S. manufacturers to compete in foreign markets.

While the value of shipments per worker increased in both export and domestic segments of manufacturing over the 1977-86 period, it increased more rapidly for export industry. In 1977, the nominal value of shipments per worker in domestic manufacturing averaged across the 48 states was $\$ 72,810$ and the value for export manufacturing was $\$ 86,520$. An analysis of 
variance test indicates that this difference is not statistically significant. However, by 1986, the nominal value of shipments per worker in export manufacturing averaged across states was $\$ 162,330$ compared with a value of $\$ 127,690$ for the domestic segment. Analysis of variance of this difference is statistically significant at the .01 level $(F=13.20)$. These large differences suggest that states may also be exporting goods with a higher than average value added component; however, this proposition cannot be confirmed because value added data are not currently compiled by export and domestic manufacturing categories.

Although the gains in export manufacturing employment, real value of shipments, and shipments per worker are impressive, the export component remains a small, but growing, segment of the overall industrial economy of the typical state. In 1977, direct export shipments as a share of total shipments averaged only 5.7 percent across states. By 1986, this share had increased to 7.0 percent, still a relatively small proportion of total manufacturing sales. Thus, it is clear that even though manufacturing exports may exert an influence on overall state economic growth, manufacturing for domestic sales remains the overwhelming driver of state economic fortunes.

Considerable variation exists among states in their exportrelated experiences over the 1977-86 period. Standard deviations for the various measures are relatively large. Eighteen states 
actually lost export manufacturing employment and four states experienced declines in real export value of shipments over the nine-year span. States also vary significantly with respect to the relative importance of the export component in their industrial economies. Export employment as a share of total manufacturing employment ranged from less than one percent to more than 11 percent in 1977, and from less than two percent to nearly 16 percent in 1986. Thus, the relationships between export performance and state industrial growth examined here must confront widely variable patterns.

Analysis of the bivariate correlations between the growth rate of export value of shipments (sales) and state industrial growth rate indicates that a significant positive relationship characterizes the study period (Table 1). The simple correlation between direct export sales growth and state manufacturing employment growth is 0.56 , while the relationship between direct exports growth and state manufacturing value added growth is 0.44. Similarly, the correlations between total (direct plus indirect) export sales and manufacturing employment growth is 0.68 and the correlation between total export sales and manufacturing value added growth is 0.55. Each of these Pearson coefficients is significant at the .01 level. Rank correlation coefficients for the respective variable pairs are also highly significant, each with a somewhat higher coefficient than the Pearson (Table 1). 
Thus, although each of the state economies is overwhelmingly driven by its domestic component, state industrial employment and output growth is not independent of growth in the export value of shipments component. However, the relative magnitude of the correlation coefficients indicates that, even in the most favorable of interpretations, other factors generally account for a substantial majority of the variation in the rates of state industrial growth.

The causal nature of the exporting--industrial growth relationship is also not unambiguous. While most public policymakers apparently believe that increased exporting enhances state industrial growth (and economic growth more generally because of linkage effects), it could also be argued that higher rates of state industrial growth make higher rates of export growth possible. Indeed, traditional regional economic theories such as the export base often are predicated on the notion of a production surplus above and beyond that needed for regional consumption that becomes available for sales to a "rest of the world" sector. Exporting thus becomes the logical extension of higher levels of output in this latter scenario.

An additional and more conservative perspective on the relationship is provided by the correlation between state industrial growth and the change in the ratio of export to domestic value of shipments growth. A positive relationship suggests that, as a state's manufacturing sector shifts more of 
its sales to foreign markets, a higher rate of state industrial employment and value added is achieved. The correlation coefficients for this relationship are given in Table 1 and, while they are positive for both the Pearson and rank correlations, neither is statistically significant or explains more than a minute share of the state-to-state variation in industrial growth. There are, of course, many intervening variables that could also affect state industrial growth, none of which are controlled in this simple relationship; the potential of the domestic sales sector to drive the relationship is certainly not the least of these.

While the independence of exporting and state industrial growth cannot be dismissed based on the evidence provided here, an explanation of the causal nature of the relationship undoubtedly awaits the analysis of firm-specific data. If manufacturing firms that engage in exporting or shift more of their sales to foreign markets are found to exhibit higher rates of employment and output growth, those proponents of policies to internationalize firms' markets will find vindication in this information.

\section{A Comparison of Industrial Growth Factors in Domestic and Export Sectors}

Over the past several decades, numerous comparative studies of state economic growth have been completed, focusing on the factors or variables that give rise to differential performance 
of these economies. These studies have typically attempted to explain either the relative or absolute increase in state employment or output over a given time period(s). Most are based on some underlying microeconomic concepts of a firm's production function. Such models provide an opportunity to examine whether export employment growth responds to the same economic and locational forces as employment growth in domestic production.

Models of State Industrial Growth

Among the more notable early models of state industrial growth relevant to this research are those of Thompson and Matilla [18] and Wheat [26]. These models regressed some measure of state industrial growth--usualy manufacturing employment change--on a substantial number of independent variables reflecting comparative costs of manufacturing and market potential. Among the independent variables included were a wide range of factors including regional or state market growth, agglomeration economies, market thresholds, urban attraction, labor costs and unionization, natural resource availability, and climate.

Two recent studies are particularly noteworthy for our analysis. Plaut and Pluta [15] and Wasylenko and McGuire [24] constructed cross-sectional models of state economic growth using regression methodologies not unlike those earlier studies noted above. These studies utilized particularly appropriate contemporary specifications of models of state industrial growth, 
focusing heavily upon business climate and state and local taxation policies in addition to traditional production cost and revenue factors as explanatory variables regressed on traditional measures of economic growth. The former study analyzed aggregate state manufacturing growth in terms of employment, real value added, and real capital stock over the 1967-77 period, while the latter study analyzed employment change in six broad manufacturing and nonmanufacturing divisions and their aggregate total over the 1973-80 period. Both of these analyses achieved considerable success in accounting for a significant share of the variation in state economic growth. 


\section{Variables, Data, and Hypothesized Relationships}

In the regression models specified below, two dependent variables are used: (1) the growth rate of employment in the manufacturing sector producing for the domestic market over the 1977-86 period, and (2) the growth rate of employment in the manufacturing sector producing for the foreign export market over the same time interval. The regressions are run across the 48 states using an ordinary least squares analysis.

The literature on state industrial growth models suggests four classes of independent variables: (1) domestic market accessibility; (2) production factor costs, e.g., land, labor, and capital; (3) climate or other physical environment variables; and (4) taxation and public expenditures [15]. Each of these classes is represented in one or more independent variables. Several of the control variables are specified in the same manner used by previous authors including Plaut and Pluta [15] and Wasylenko and McGuire [24].

The model specified here is a disequilibrium-adjustment model commonly used in cross-sectional analyses [15]. Producers are assumed to adjust in response to the levels of input prices and locational variables at the start of the period. Because changes occur slowly in most independent variables, and firms also do not respond instantaneously to these changes, the effects of firms' investment decisions are experienced over a time horizon of several years. Furthermore, the relative positions of 
states in the statistical distributions of the independent variables tend to change slowly over time.

Domestic market accessibility $\left(\mathrm{MP}_{j}\right)$ in state $j$ is measured by the ratio of personal income potential ( $\mathrm{PYP}_{j}$ ) to manufacturing value added potential $\left(\operatorname{VAP}_{j}\right)$ following Plaut and Pluta's [15] formulation based on a standard gravity model,

$$
\begin{aligned}
\mathrm{MP}_{j} & =\mathrm{PYP}_{j} / \mathrm{VAP}_{j} \\
\mathrm{PYP}_{j} & =\underbrace{49}_{j=1} \mathrm{PY}_{j} / \mathrm{d}_{i j} \\
\text { and } \mathrm{VAP}_{j} & =\mathrm{EA}_{j=1}^{49} / \mathrm{d}_{i j} .
\end{aligned}
$$

$\mathrm{PY}_{j}$ and $\mathrm{VA}_{j}$ are total personal income and manufacturing value added in state $j$, respectively, and $d_{i j}$ is the distance between the centroid of population (1980) in state $j$ and each of the other states. ${ }^{3}$ A state's own potential within its borders is measured by one half the average distance from its centroid to those of contiguous states. No attempt has been made to adjust personal income figures for state-to-state differences in buying power; reliable cross-state estimates do not exist. Where personal income potential (demand) is high relative to value added potential (supply), we expect that higher market potential

${ }^{3}$ The District of Columbia was included as a potential market and source of supply in the calculation of this variable. Exponents for the distance variable were also used in an attempt to better reflect the frictional effects of distance in market access; however, these alterations did not improve the performance of the model over and above that of the simple linear specification, and so the latter was used. 
will exert a positive effect on state domestic manufacturing employment growth. In contrast, we anticipate that a lower market potential will induce a state's industrial firms to seek foreign export markets, a traditional argument in the international business literature $[11 ; 16 ; 22]$. Consequently, we anticipate that this latter relationship will be inverse. The remaining variables are expected to affect both domestic and export employment growth in the same respective direction of relationship.

Labor costs, availability, skills (productivity), and labormanagement relations are represented by four variables. Direct labor costs are measured by the average hourly wage in manufacturing, expected to be negatively related to manufacturing employment growth. Labor supply is measured by the average annual unemployment rate, expected to have positive coefficients. The labor relations environment is measured using the Alexander Grant and Company [2] manufacturing business climate scores for the 48 contiguous states. The manufacturing environment is determined by a scoring system for the attractiveness of 18 different production factors; over 60 percent of the weight in the score is derived from a combination of state-regulated employment costs, labor costs, and the availability and productivity of the labor force. These components include such factors as the level of and changes in unionization rates, manhours lost due to strikes, and unemployment and workers 
compensation payments and benefits. Thus, states with a high numerical score (more favorable labor relations environments) are expected to experience higher rates of domestic and export employment [3] and the coefficients on this variable should be positive. Labor skills and associated productivity are proxied by the percentage of the population aged 25 and over with four or more years of college. While other studies have used median years of education as an explanatory variable, there is currently little variation across states in either the median years of schooling or the percentage of the population that has graduated from high school. College education therefore appears to be a more relevant discriminatory variable in an era of higher technology manufacturing and a decreasing proportion of production workers as a share of total manufacturing employees. A positive sign is anticipated for these regression coefficients.

The cost of land is measured by factor scores derived from a principal components analysis of the states' value of agricultural land and buildings per acre and the population density [15]. High land values and high population densities yielding high factor scores for states are expected to be negatively related to employment growth. No account is made for state-tostate differences in capital costs given the unavailability of such data and the presumption of minimal geographic variation in

${ }^{4}$ The first factor identified in the analysis accounted for 91 percent of the variation in the data. 
the price of this input.

Energy prices are reflected in two variables. One is the real cost per million BTU's of purchased fuels and electricity in manufacturing, expected to be negatively related to state employment growth. The other is a state's ratio of its share of energy produced in the nation to its share of energy consumed where energy supply is based on the value of shipments of crude petroleum and natural gas, liquified petroleum gas, and bituminous and anthracite coal and energy consumed is based on the total BTU's of energy consumed. This variable might be expected to have a positive relationship to manufacturing employment growth, given the implication of a higher supply to demand ratio yielding lower prices. However, the collapse of world petroleum prices (and, by substitution effects, some other competing fuels) that occurred during our analysis period had devastating consequences for manufacturing in many of the "energy-rich" states where petroleum-related manufactures and linked industrial sectors were severely shocked. As a result, we anticipate negative effects on growth in these states.

Location specific amenities related to climate and potential climate-related costs of heating and/or cooling are included in the model to test whether firms avoid or are induced to expand in certain types of climates [24]. A principal components analysis was again used to derive factor scores. Four climate variables were entered including the normal daily mean temperature, the 
mean annual precipitation, the average annual percentage of possible sunshine, and the number of months in which the normal daily maximum exceeds 85 degrees $F$. or the normal daily minimum is lower than 55 degrees $F$. This set of climate variables is similar to that used by Plaut and Pluta [15]. The factor scores for two principal components are entered in the regression analysis. ${ }^{5}$ The first dimension is defined by high positive loadings on the precipitation and monthly extremes variables, characteristic of many of the states in the eastern (particularly southeastern) part of the nation. The second dimension is defined by high positive loadings on the temperature and sunshine variables, more typical of many of the states in the southwestern part of the country. Based on precipitation and temperature extremes, we anticipate the first of the climate variables to be negatively related to manufacturing employment growth; based on sunshine and higher temperatures, we expect the second to be positively related to growth.

Three variables are used to reflect the state's fiscal priorities. One variable is Wheaton's [27] ratio of business tax burden to business net income, which should be negatively related to state growth, i.e., a lower ratio implies enhanced growth prospects. Other variables include state and local expenditures on education and welfare, respectively, as percentages of state

${ }^{5}$ The first and second factors accounted for 54 and 37 percent of total variation, respectively. 
personal income. The former is expected to be positively related to growth while the latter should be negatively related.

Two other location specific attribute variables complete the analysis set. Agglomeration economies are defined as the employment in manufacturing divided by the land area of the state. Agglomeration economies are anticipated to confer cost savings on firms and, as a result, be positively related to growth. A final variable attempts to control for differences in industry mix among states by measuring a "high technology" component of industrial structure. This variable is defined as the share of a state's total manufacturing value of shipments represented by 18 3-digit SIC industries used by the International Trade Administration to identify high technology trade sectors. ${ }^{6}$ States with a higher proportion of value of shipments in high technology sectors should experience higher rates of growth.

Data for each of the independent variables were used to reflect as closely as possible conditions at the beginning of the analysis period. Documentation of the data and more detail concerning the construction of certain variables are provided in

${ }^{6}$ While more sectorally disaggregated measures of high technology industries exist, the 3-digit SIC level of disaggregation is the most detailed that can be supported in geographic data tabulations of the Annual Survey of Manufactures. The SIC's included in this classification are 281, 282, 283, 348, $351,357,365,366,367,372,376,381,382,383,384,385,386$, and 387. This classification was formulated at the International Trade Administration by Lester Davis [4]. 
the Appendix.

\section{Regression Results}

Results from the regression specified for domestic manufacturing employment growth over the 1977-86 period indicate that the model performed well in terms of overall variation explained (Table 2). The coefficient of determination is 0.76 and the F-ratio indicates that the equation is highly significant. The level of explained variation is nearly identical to that achieved by Plaut and Pluta [15] for total state employment growth for an earlier decade and somewhat higher than Wasylenko and McGuire [24] obtained in their model of state employment growth over the 1973-80 period.

Inspection of the coefficients for the independent variables in the domestic manufacturing employment equation also yields some interesting results. As anticipated, the market potential coefficient is positive and significant. Manufacturing for domestic markets apparently has continued to be attracted to regions with growing markets during the past decade, as found in some earlier studies $[15 ; 18 ; 26]$.

Among the variables related to the labor force, all but the manufacturing (labor) environment variable have the right signs, but none have statistically significant coefficients. Indeed, earlier studies have demonstrated conflicting findings on the wage influence $[18 ; 24 ; 26]$. Those business leaders and state public officials who put considerable stock in the business 
climate rankings issued by Alexander Grant and Company (now Grant Thornton) [2] will be disappointed with the absence of any significant positive relationship between business climate and domestic manufacturing employment growth. Similarly, the percentage of the population aged 25 or over with four or more years of college was not a significant influence on domestic employment growth.

With respect to the energy variables, as expected, the energy supply/demand ratio is consistently negative and significant, clearly demonstrating the adverse effects of declining energy pri2ces on industrial growth in the once "high flying" energy-rich states. However, contrary to expectations, the energy costs variable is positive and significant. This finding most likely reflects the declining relative importance of energy costs to most domestic manufacturing industries over the study period; declining real energy costs since the early 1980's have removed, at least partially, a previous impediment to expansion in the energy-poor states where energy prices generally remain relatively higher.

The land cost variable exhibits a negative and significant relationship to domestic manufacturing employment growth. However, the presence of a high degree of collinearity between the land cost and agglomeration economies variables, both of which reflect high development densities, dictated that the 
latter variable be dropped in the regressions. ${ }^{7}$

With respect to physical elements of climate, only the coefficient for the second climate variable (warm and sunny) derived from principal components analysis scores was significant with the hypothesized positive relationship, indicative of continuing domestic manufacturing employment growth in southwestern states. However, the temperature extremes and greater precipitation of states elsewhere in the nation had no significant adverse effects on domestic manufacturing growth.

The variables reflecting public tax and spending policies present mixed results. Each has the expected sign, although the welfare spending variable is the only significant one. The negative, but insignificant, coefficient on the tax ratio variable suggests that manufacturing oriented to domestic markets was not significantly swayed against those states, notably those in the Northeast and West Coast, that are characterized by relatively higher tax burdens on manufacturing businesses.

Finally, the high technology industry structure variable has the expected positive sign, and it is highly significant in the domestic manufacturing employment growth equation. This finding

${ }^{7}$ With the exception of the agglomeration economies and land cost variables noted, an examination of simple correlation coefficients between pairs of independent variables indicated no values sufficiently high to suggest multicollinearity effects on the estimates. However, additional regressions were performed on some pairs that confirmed the initial conclusion. In addition, there was no evidence of heteroskedasticity or spatial autocorrelation among the residuals from regression. 
indicates that manufacturers oriented to the domestic market have fared well over the past decade in states where the industry mix had more technologically advanced industries.

In contrast, the regression model specified for export manufacturing employment growth did not perform nearly as well as that for domestic growth (Table 2). Although the F-ratio (3.13) indicates that the entire equation is statistically significant, the coefficient of determination is only 0.39, with only about half the explanatory power of the previous equation. It is also interesting to observe that there are only two common variables between the two equations that are statistically significant, and the signs on one variable are opposite. Thus, there are clearly different underlying forces that promote state employment growth in export as opposed to domestic manufacturing.

In the export case, a substantial share of the growth forces lies in the traditional labor variables. Relatively lower manufacturing wages apparently make industries more competitive in international markets, despite a popular public image that the U.S. only exports high value added commodities produced by higher wage labor. The simple correlation between export manufacturing growth and the wage rate is also negative. The labor supply variable proxied by the unemployment rate is positive and significant, while the college-educated share of the population just misses statistical significance with the hypothesized sign. The labor relations/business climate variable is significant but 
has a sign opposite that which would be expected, further evidence of the mythical nature of state business climate rankings and an indication that past labor relations problems of the more heavily unionized states have dissipated, at least with respect to export manufacturing employment growth.

Although the coefficients for the energy markets and costs of electricity variables have the expected signs, neither comes close to an acceptable level of statistical significance. This finding stands in contrast once again to the results for domestic manufacturing employment growth. As anticipated, those states with high loadings on the precipitation and temperature extremes did not fare as well as others in export manufacturing employment growth.

The manufacturing tax ratio variable is significant and again carries the anticipated negative sign. Apparently, exportoriented manufacturers are more sensitive to high manufacturing tax burdens than domestic market producers, perhaps believing that such taxes can be shifted more easily in the domestic market. The welfare spending variable is again negative and significant.

The final statistically significant coefficient is the high technology industry variable; however, it carries a negative sign. This finding may result from the relatively crude measure of high technology industry derived from 3-digit SIC data. While domestic manufacturers may achieve higher employment growth rates 
in these broad industry groups, exporters must apparently find product niches in more specialized sectors. Abbott, et al. [1] have concluded in a recent study that, at the level of individual products, high technology sectors are performing well in export markets; however, the low technology goods produced by the aggregate high tech industries are experiencing significant international competition.

\section{Conclusions}

The research presented here has begun to explore an issue of considerable contemporary significance, the relationship between export performance and state industrial growth. State governments currently expend considerable scarce resources on export promotion activities with little understanding of the actual or potential benefits to be achieved. Perhaps because the national trade deficit and the perceived need for export development policies have gained such widespread public exposure in recent years, states also have assumed that exporting is a key to enhanced industrial growth.

Despite the very rapid average growth rates of manufacturing export employment and value of shipments across states over the past decade, manufacturing for the domestic market remains the overwhelmingly dominant driver of states' economic fortunes. Export performance in terms of the growth in value of shipments for both direct and total export activities is positively and significantly correlated with overall state manufacturing 
employment and value added increases over the 1977-86 period. However, the direction of the causality involved in this relationship is not firmly established, and numerous potential intervening variables have not been taken into account. Furthermore, the shift of manufacturing sales from domestic to foreign markets is not significantly correlated with higher rates of state industrial growth.

Further elucidation of the relationship between export performance and state industrial growth will require the analysis of data at the enterprise level. The linchpin in this relationship is whether firms that sell in foreign markets experience higher rates of output and employment growth than those that produce for domestic markets. An equally important question in the cases of multi-establishment enterprises is what states are the ultimate beneficiaries of the employment and output growth that a firm may achieve.

Product cycle theory--despite its inherent deficiencies--and other behavioral theories of exporting from the international trade and business literature provide potential starting points for a more thorough examination of the export performance and state industrial growth relationship. These theories suggest that exporter firms are likely to be those with outputs in the growth phase of the product cycle $[10 ; 23 ; 25]$, with products characterized by more advanced technologies [9;12], and a strategic management orientation toward risk-taking and more 
aggressive marketing tactics [12]--in short, firms with high growth potential. Examination of the export performance and state industrial growth relationship must also incorporate and test theories of the spatial organization of multiunit enterprises in order to link exporting firm's growth experiences with their various operations in particular states.

The comparison of industrial growth factors in domestic and export sectors also provides some interesting results. While a very high proportion of variation in states' domestic manufacturing employment growth rates was explained by traditional industrial growth factors, the same factors explained only half as much of the variation in the export manufacturing employment growth rate. Furthermore, only one common statistically significant factor characterized the two models. For the domestic manufacturing sector, market access, the energy situation, land costs, industry structure, and warm and sunny climates were most important; in contrast, human resources and manufacturing tax burdens accounted for a substantial share of the explained variation in export manufacturing employment growth.

Whether state governments can effectively stimulate export performance among their respective manufacturing sectors remains an open question. In any case, policies for export promotion should not divert attention from efforts to promote enhancements in the domestic sector of the manufacturing economy. Policy- 
makers must also realize that industrial export growth is less responsive to traditional factors underpinning state industrial growth than the larger, domestic manufacturing sector. If states continue to pursue export promotion policies--and there is no reason to believe that they will not--more effective policies should be crafted from theoretical and empirical inquiry into the nature of firms' export decisions and their ultimate consequences for the enterprise and the location(s) of its operations. 


\section{Literature Cited}

1. Abbott, $\mathrm{T}$. , et al, "Measuring the Trade Balance in Advanced Technology Products," Discussion Paper CES 89-1, U.S. Bureau of the Census, Center for Economic Studies, Washington, DC, 1989.

2. Alexander Grant and Company, General Manufacturing Business Climates, Chicago: Alexander Grant and Company, 1980.

3. Bartik, T., "Business Location Decisions in the U.S.: Estimates of the Effects of Unionization, Taxes and Other Characteristics of States," Journal of Business and Economic Statistics, 3 (1985), pp. 14-22.

4. Davis, L., "Technology Intensity of U.S. Output and Trade," unpublished manuscript, U.S. Department of Commerce, International Trade Administration, Washington, DC, 1982.

5. Fieleke, N.S., "New England Manufacturing and International Trade," New England Economic Review of the Federal Reserve Bank of Boston, (September/October 1986), pp. 22-28.

6. Florida Department of Commerce, The Impact of Foreign Trade on Florida's Economy, Tallahassee, Florida: Florida Department of Commerce, 1989.

7. Gillespie, R.W., "The Midwest Region and the International Economy," in The Midwest Economy: Issues and Policy, edited by R.W. Resek and R.F. Kosobud, Urbana, Illinois: University of Illinois, 1982 .

8. Griffin, A.H., California Exports: Their Contribution to the Economy, Sacramento, California: California Department of Commerce, 1989.

9. Hayward, D.J. and R.A. Erickson, "The Export Orientation of New Small Firms," unpublished manuscript, Center for Regional Business Analysis, College of Business Administration, The Pennsylvania State University, University Park, Pennsylvania, 1989 .

10. Hirsch, S., The Export Performance of Six Manufacturing Industries, New York: Praeger, 1971.

11. McConnell, J.E., "Promoting U.S. Exports Through More Effective Communication Between Government and Business, " Journal of Business Communication, 15 (1977), pp. 3-18.

12. McConnell, J.E., "The Export Decision: An Empirical Study of Firm Behavior," Economic Geography, 55 (1979), pp. 171-83. 
13. McConnell, J.E., "Employment Gains from U.S. Exports: Winning and Losing Sectors and States in 1983 and 1990." Paper presented at the Annual Meeting of the Association of American Geographers, Portland (Oregon), April 1987.

14. National Association of State Development Agencies, State Export Promotion Database, Washington, DC: National Association of State Development Agencies, 1988.

15. Plaut, T.R., and J.E. Pluta, "Business Climate, Taxes and Expenditures, and State Industrial Growth in the U.S.," Southern Economic Journal, 50 (1983), pp. 99-119.

16. Simpson, C.L. and D. Kujawa, "The Export Decision Process: An Empirical Inquiry," Journal of International Business Studies, 5 (1974), pp. 107-117.

17. Smith, T.R., "Regional Exports of Manufactured Products," Economic Review of the Federal Reserve Bank of Kansas City, 74 (January 1989), pp. 21-31.

18. Thompson, W.R. and J.M. Matilla, An Econometric Model of Postwar State Industrial Development, Detroit: Wayne state University Press, 1959.

19. U.S. Bureau of Economic Analysis, "U.S. National Income and Product Accounts: 1965-68," Survey of Current Business, 49 (July 1969), pp. 13-49.

20. U.S. Bureau of Economic Analysis, "The U.S. National Income and Product Accounts: Revised Estimates," Survey of Current Business, 69 (July 1989), pp. 8-37.

21. U.S. Bureau of the Census, Statistical Abstract of the United States: 1989. Washington, DC: U.S. Government Printing Office, 1989 .

22. Ursic, M.L. and M.R. Czinkota, "An Experience Curve Explanation of Export Expansion," Journal of Business Research, 12 (1984), pp. 159-68.

23. Vernon, R., "International Investment and International Trade in the Product Cycle," Quarterly Journal of Economics, 80 (1966), pp. 190-207.

24. Wasylenko, M. and T. McGuire, "Jobs and Taxes: The Effect of Business Climate on States' Employment Growth Rates," National Tax Journal, 38 (1985), pp. 497-511.

25. Wells, L.T., The Product Cycle and International Trade, Cambridge, Massachusetts: Harvard University Press, 1972. 
26. Wheat, L.F., Regional Growth and Industrial Location (Lexington, Massachusetts: DC Heath and Company, 1973).

27. Wheaton, W.C., "Interstate Differences in the Level of Business Taxation," National Tax Journal, 36 (1983), pp. 83-95. 


\section{Appendix}

\section{Data Sources and Methodological Notes}

Employment, Value Added, Direct and Total Exports Value of Shipments Growth 1977-86:

U.S. Bureau of the Census, Census of Manufactures, 1977 and Annual Survey of Manufactures, 1986. Where reported, real value added and value of export or export-related shipments were derived with an implicit price deflator for manufacturing (unpublished) provided by the U.S. Bureau of Economic Analysis.

Market Access 1977:

U.S. Bureau of Economic Analysis, "State Personal Income, 1977-83: Revised Estimates," Survey of Current Business, 64 (August 1984), pp. 41-53. Value added data derived from U.S. Bureau of the Census documents listed above. State centroids based on Census data and estimated state-to-state distances calculated using computer program developed by Kenneth Beck.

Hourly Manufacturing Wage and Unemployment Rate 1977:

U.S. Bureau of Labor Statistics, Employment and Earnings, May 1979.

Manufacturing (Labor) Environment 1980:

See $[2]$.

Percentage of Population 25 or Older with Four or More Years College 1980:

U.S. Bureau of the Census, Census of Population, 1980 .

Energy Supply/Demand Ratio 1977-78:

Data on value of shipments of energy fuels production including coal, crude petroleum and natural gas, and liquified petroleum gas are from U.S. Bureau of the Census, Census of Mineral Industries, 1977. Data on energy consumption in BTU's for 1978 are from U.S. Energy Information Administration, State Energy Data Report, 1980.

Energy Cost Per MBTU of Purchased Fuels and Electricity 1977: 
U.S. Bureau of the Census, Census of Manufactures, 1977. 
Land Costs 1978 and 1982 :

Value of agricultural land and buildings per acre was taken from U.S. Bureau of the Census, Census of Agriculture, 1978 . Population density data were taken from U.S. Bureau of the Census, Statistical Abstract of the United States, 1979.

Climate 1 and Climate 2:

Normal daily mean temperature (F.), mean annual precipitation, average annual percentage of possible sunshine, and the number of months in which the normal daily maximum exceeds 85 degrees F. or the normal daily minimum is below 55 degrees $F$. were all taken from Statistical Abstract of the United States, 1989.

Manufacturing Tax Ratio 1977:

Wheaton's [27] methodology and sources of data, with one exception, were used to derive the ratio of manufacturing taxes to net income. Manufacturing net income is defined as gross state product (GSP) minus manufacturing payroll. State and local taxes included in the ratio are property, corporate income, unemployment compensation, and license fees. All tax estimates were made using U.S. Bureau of the Census, State Government Tax Collections, or Census of Governments reports for 1977. The exception is GSP, for which more reliable GSP estimates became available since Wheaton's research was completed; these were taken from Renshaw, V., E. A. Trott, Jr., and H. L. Friedenberg, "Gross State Product by Industry, 1963-1986," Survey of Current Business, 74 (May 1988), pp. $30-46$.

Education and Welfare Spending as a Percentage of State Personal Income 1977:

Education and public welfare expenditures were taken from U.S. Bureau of the Census, State Government Finances, 1977. State personal income data were taken from the Survey of Current Business publication referenced for the Market Access variable.

High Tech Industry Value of Shipments as a Percentage of Total Shipments 1983:

See footnote 7. Compiled with unpublished data from the Industry Division of the U.S. Bureau of the Census. Data prior to 1983 were unavailable at this disaggregated level. 
TABLE 1

CORRELATION COEFFICIENTS BETWEEN EXPORT PERFORMANCE

AND STATE INDUSTRIAL GROWTH MEASURES: 1977-86

Pearson Correlation

(Spearman Rank-Order Correlation)

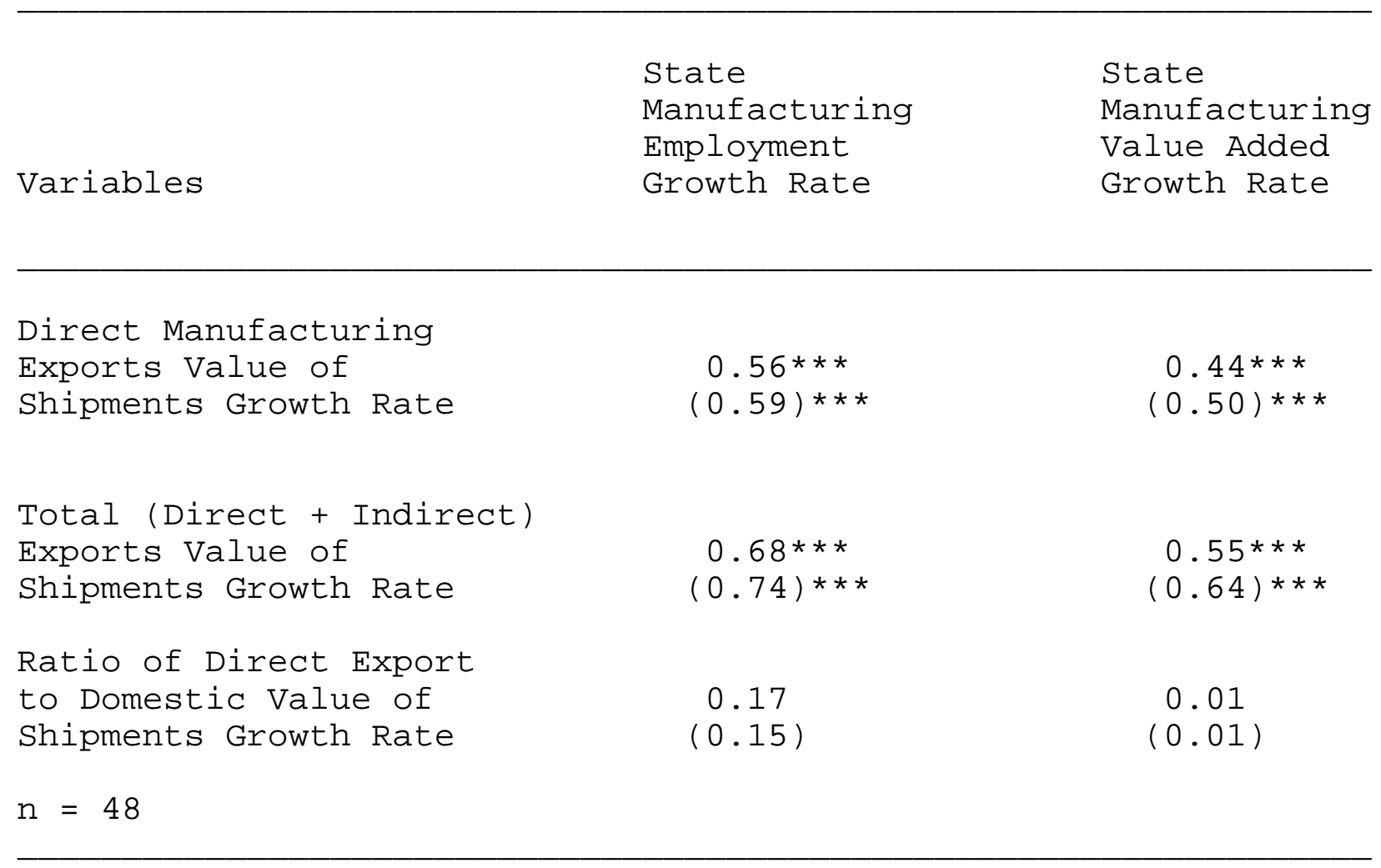

***statistically significant at the 0.01 level 
TABLE 2

REGRESSION RESULTS FOR ANALYSIS OF STATE DOMESTIC AND EXPORT MANUFACTURING EMPLOYMENT GROWTH: 1977-86

\begin{tabular}{|c|c|c|}
\hline $\begin{array}{l}\text { Independent } \\
\text { Variables }\end{array}$ & $\begin{array}{l}\text { Domestic } \\
\text { Manufacturing } \\
\text { Employment } \\
\text { Growth Rate }\end{array}$ & $\begin{array}{l}\text { Export } \\
\text { Manufacturing } \\
\text { Employment } \\
\text { Growth Rate }\end{array}$ \\
\hline Market Potential & $\begin{array}{l}0.2150 * \\
(1.52) \mathrm{a}\end{array}$ & $\begin{array}{r}-0.5033 \\
(-0.34)\end{array}$ \\
\hline Manufacturing Wage Rate & $\begin{aligned}-0.0120 \\
(-0.59)\end{aligned}$ & $\begin{array}{l}-0.7924 * * \\
\quad(-2.25)\end{array}$ \\
\hline Unemployment Rate & $\begin{array}{r}0.0033 \\
(0.29)\end{array}$ & $\begin{array}{l}0.3565 * \star \star \\
(2.96)\end{array}$ \\
\hline Manufacturing (Labor) Environment & $\begin{array}{r}-0.0008 \\
(-0.24)\end{array}$ & $\begin{array}{l}-0.0601 * \star \\
(-1.73)\end{array}$ \\
\hline College Educated & $\begin{array}{l}0.0002 \\
(0.01)\end{array}$ & $\begin{array}{r}0.1898 \\
(1.30)\end{array}$ \\
\hline Energy Supply/Demand Ratio & $\begin{aligned} &-0.0340 * \star \star \\
&(-3.55)\end{aligned}$ & $\begin{array}{l}0.0775 \\
(0.77)\end{array}$ \\
\hline Energy Costs & $\begin{array}{l}0.0972 * \star \star \\
(3.06)\end{array}$ & $\begin{array}{l}0.0006 \\
(0.00)\end{array}$ \\
\hline Land Costs & $\begin{array}{l}-0.0571 * \star \star \\
(-3.52)\end{array}$ & $\begin{array}{r}-0.1686 \\
(-0.99)\end{array}$ \\
\hline Climate 1 (Precipitation \& Extremes & s) $\begin{aligned}- & 0.0062 \\
& (-0.46)\end{aligned}$ & $\begin{array}{l}-0.5137 * \star \star \\
(-3.68)\end{array}$ \\
\hline Climate 2 (Warm and Sunny) & $\begin{array}{l}0.0416 * * \\
(2.44)\end{array}$ & $\begin{array}{l}0.2002 \\
(1.12)\end{array}$ \\
\hline Manufacturing Tax Ratio & $\begin{aligned}-0.7275 \\
(-0.87)\end{aligned}$ & $\begin{array}{c}-18.8019 \star \star \\
(-2.15)\end{array}$ \\
\hline Education Spending & $\begin{array}{r}1.1223 \\
(0.74)\end{array}$ & $\begin{array}{r}-11.2551 \\
(-0.71)\end{array}$ \\
\hline Welfare Spending & $\begin{array}{c}-4.9206 * \star \\
(-1.81)\end{array}$ & $\begin{array}{c}-51.4799 \star \star \\
(-1.81)\end{array}$ \\
\hline High Technology Industry & $\begin{array}{c}0.0038 * \star \\
(2.20)\end{array}$ & $\begin{array}{r}-0.0245 * \\
(-1.35)\end{array}$ \\
\hline $\begin{array}{l}\overline{\mathrm{R}}^{2} \\
\mathrm{n}=48\end{array}$ & .76 & .39 \\
\hline
\end{tabular}

*statistically significant at the 0.10 level using one-tailed test ** statistically significant at the 0.05 level using one-tailed test ***statistically significant at the 0.01 level using one-tailed test 
$a_{t-s t a t i s t i c s}$ are given in parentheses 